\title{
DETERMINASI MOTIVASI BERPRESTASI TERHADAP KINERJA KARYAWAN PADA AUTOTAMA MOBIL MOTOR DI KARANGASEM
}

Putri Anggreni

Fakultas Ekonomi Universitas Mahendradatta Denpasar

gekcay@gmail.com

\begin{abstract}
Achievement motivation is an encouragement in a person to do a particular task or activity or task as well as possible in order to achieve a commendable achievement with honors. Seeing these indications, the performance of employees in the Motor Car Autotama Karangasem is influenced by several variables. One of them is the achievement motivation, but how much the relationship or the determination of achievement motivation on employee performance Autotama Motor Cars is not certain. Therefore, this study will examine the determination of achievement motivation on employee performance Autotama Car Motor Karangasem Data achievement motivation and performance of employees that have been collected tabulated the mean, median, mode, the range, scale and standard deviation of data concerning achievement motivation and performance of employees. Statistical analysis was used to test the hypothesis with a simple linear regression. The stages of the analysis conducted in this study is a description of the data. Qualification data description achievement motivation and performance of employees, also using univariant analysis. This analysis is based on the average score of the ideal (Mi) and the ideal standard deviation (SDi). As well as this analysis also includes testing requirements analysis and hypothesis testing. The analysis showed that there was a significant correlation between the Achievement Motivation Employee Performance through the equation of the line $y=-36.800+0.632 X$ with Freg $=43.015(p<0.05)$. In the present study found a significant correlation between the achievement motivation employee performance at 0.691 with $p<0.05$. This means that the better the achievement motivation of employees, the better the performance of the employee. Achievement motivation variables could explain the higher performance of employees amounted to 47.8\%. These findings indicate that achievement motivation has an important role in improving employee performance. Normatively found that achievement motivation as very good in the category means an employee has shown excellent achievement motivation in carrying out his job. From the correlation analysis it is evident that significant determination between the achievement motivation employee performance. It needs to be maintained to keep employees comfortable and satisfied in performing everyday tasks so that corporate objectives will be achieved.
\end{abstract}

Key Words: achievement motivation, employee performance, Autotama Motor Cars, corporate objective 


\begin{abstract}
ABSTRAK
Motivasi berprestasi merupakan suatu dorongan dalam diri seseorang untuk melakukan atau mengerjakan suatu kegiatan atau tugas dengan sebaik-baiknya agar mencapai prestasi dengan predikat terpuji. Melihat indikasi tersebut, kinerja karyawan pada Autotama Mobil Motor di Karangasem dipengaruhi oleh beberapa variabel. Salah satu diantaranya adalah motivasi berprestasi, namun seberapa besar hubungan atau determinasi dari motivasi berprestasi terhadap kinerja karyawan Autotama Mobil Motor belum diketahui secara pasti. Maka dari itu, penelitian ini akan meneliti tentang determinasi motivasi berprestasi terhadap kinerja karyawan Autotama Mobil Motor di Karangasem. Data motivasi berprestasi dan kinerja karyawan yang sudah dikumpulkan ditabulasi rerata, median, modus, rentangan, besaran dan simpangan baku menyangkut data motivasi berprestasi dan kinerja karyawan. Analisis statistik yang digunakan untuk menguji hipotesis adalah dengan regresi linier sederhana. Adapun tahapan analisis yang dilakukan dalam penelitian ini yaitu deskripsi data. Kualifikasi pendeskripsian data motivasi berprestasi dan kinerja karyawan, juga menggunakan analisis univariant. Analisis ini didasarkan pada skor rata-rata ideal (Mi) dan simpangan baku ideal (SDi). Serta analisis ini juga meliputi uji prasyarat analisis dan uji hipotesis. Hasil analisis menunjukkan bahwa terdapat korelasi yang signifikan antara motivasi berprestasi dengan kinerja karyawan melaui persamaan garis $\hat{y}=-36,800+0,632 X$ dengan Freg $=43,015(p<0,05)$. Dalam penelitian ini ditemukan korelasi yang signifikan antara motivasi berprestasi dengan kinerja karyawan sebesar 0,691 dengan $\mathrm{p}<0,05$. Ini berarti makin baik motivasi berprestasi karyawan, makin baik kinerja karyawan tersebut. Variabel motivasi berprestasi dapat menjelaskan kinerja karyawan sebesar 47,8\%. Temuan ini mengindikasikan bahwa motivasi berprestasi mempunyai peranan penting dalam meningkatkan kinerja pegawai. Secara normatif ditemukan bahwa motivasi berprestasi berada pada kategori sangat baik artinya pegawai sudah menunjukkan motivasi berprestasi yang sangat baik dalam menjalankan pekerjaannya. Dari hasil analisis korelasi diketahui terdapat determinasi yang signifikan antara motivasi berprestasi dengan kinerja karyawan. Hal tersebut perlu dipertahankan agar karyawan selalu nyaman dan puas dalam melaksanakan tugas sehari-hari sehingga tujuan perusahaan akan tercapai. Kata Kunci: motivasi berprestasi, kinerja karyawan, Autotama motor mobil, tujuan perusahaan
\end{abstract}

PENDAHULUAN

Pekerjaan secara umum didefinisikan sebagai sebuah kegiatan aktif yang dilakukan oleh manusia. Dalam arti sempit, istilah pekerjaan digunakan untuk suatu tugas atau kerja yang menghasilkan sebuah karya bernilai imbalan dalam bentuk uang bagi seseorang. Dalam pembicaraan seharihari istilah pekerjaan dianggap sama dengan profesi. Pekerjaan yang dijalani seseorang dalam kurun waktu yang lama disebut sebagai karier. Seseorang mungkin bekerja pada beberapa perusahaan selama kariernya tapi tetap dengan pekerjaan yang sama.

Pada dunia kerja, tidak bisa terlepas dari adanya karyawan atau pegawai. Menurut Robbins (2006), pegawai adalah “orang pribadi yang bekerja pada pemberi kerja, baik sebagai pegawai tetap atau tidak, berdasarkan kesepakatan kerja baik tertulis maupun tidak tertulis, untuk melaksanakan suatu pekerjaan dalam jabatan atau kegiatan tertentu yang ditetapkan oleh pemberi kerja". Sedangkan menurut Soedaryono (2000) pengertian pegawai adalah "seseorang yang melakukan penghidupannya dengan bekerja dalam kesatuan organisasi, baik kesatuan kerja pemerintah maupun kesatuan kerja swasta". Berdasarkan pemaparan di atas dapat disimpulkan bahwa pegawai adalah pribadi yang bekerja pada suatu instansi maupun perusahaan.

Seorang karyawan tidak terlepas dari kinerjanya terhadap perusahaan. Istilah kinerja sering digunakan dalam penelitian yang bersifat ilmiah berkenaan dengan proses kerja yang telah dilakukan oleh individu atau kelompok. Kinerja berasal dari istilah "performance" atau unjuk 
kerja. Menurut Kane (1996) kinerja bukan merupakan karakteristik seseorang, seperti bakat atau kemampuan, tetapi merupakan perwujudan dari bakat atau kemampuan itu sendiri. Hal ini dimaksudkan bahwa kinerja merupakan perwujudan dari kemampuan dalam bentuk karya nyata. Kinerja dalam jabatan berarti hasil yang dicapai yang berkaitan dengan fungsi jabatan dalam periode waktu tertentu. (Kane, 1996). Prawirosentono (1999) mendifinisikan kinerja sebagai hasil kerja yang dapat dicapai oleh seseorang atau sekelompok orang dalam suatu organisasi dalam rangka upaya mencapai tujuan secara legal.

Salah satu faktor yang mempengaruhi kinerja pegawai adalah motivasi berprestasi. Motivasi berprestasi dalam diri individu ditandai dengan munculnya keinginan untuk memperoleh keunggulan dalam melaksanakan setiap kegiatan. Dengan perkataan lain, orang yang memiliki motivasi berprestasi tinggi akan selalu berupaya agar setiap kegiatan yang dilaksanakan mencapai hasil yang terbaik.

Pekerjaan yang menantang bagi orang yang memiliki motivasi berprestasi tinggi merupakan pemicu berusaha lebih keras, karena pekerjaan tersebut biasanya tidak mudah dikerjakan dan diselesaikan. Pekerjaan menantang menuntut seseorang untuk berpikir lebih keras, bekerja lebih tekun dan serius dan semangat yang tinggi. Selain itu, pekerjaan menantang akan menimbulkan suatu ketidakseimbangan dalam diri seseorang yang disebabkan oleh adanya kebutuhan untuk mencapai hasil yang terbaik. Pekerjaan yang terukur akan memberi gambaran yang jelas tentang apa yang akan dicapai dan sampai dimana pekerjaan itu harus dilaksanakan. Dengan demikian pekerjaan yang terukur memungkinkan seseorang dapat menilai apakah hasil yang dicapai telah sesuai dengan harapan. Kondisi seperti ini sangat diperlukan dalam melakukan suatu pekerjaan karena target yang harus dicapai terumuskan dengan jelas. Target-target yang harus dicapai biasanya dirumuskan dalam bentuk tujuan-tujuan yang lebih operasional.

Berdasarkan pemaparan di atas, dapat disimpulkan bahwa motivasi berprestasi seorang karyawan sangat mempengaruhi kinerja karyawan. Semakin tinggi motivasi berprestasi seorang karyawan, semakin tinggi pula kinerja karyawan tersebut.

Salah satu perusahaan yang ada di Kabupaten Karangasem adalah Autotama Mobil Motor. Autotama mobil motor merupakan sebuah perusahaan otomotif yang bergerak di bidang perbengkelan yang melayani bidang: spare part, salon mobil, tire service, perbaikan kendaraan, cat dan body repair serta kafetaria, yang menyediakan berbagai macam pelayanan jasa dan barang yang terdiri dari: 1) cuci mobil dan sepeda motor, 2) salon mobil (poles body, poles mesin, poles kaca, interior, mesin, dll), 3) service ringan atau tune up, 4) over haul atau service berat, 5) understel, 6) ganti oli dan gemuk, 7) ban, balancing, spooring, tubles, vulkansir, gas nitrogen (angin ban), 8) cat, las, getok 
body, 9) accu dan stroom accu, 10) spare part, variasi dan aksesoris lainnya. Perusahaan ini beroprasi dengan jumlah karyawan sebanyak 49 orang yang masingmasing karyawannya memiliki kinerja yang berbeda-beda.

Mengenai motivasi berprestasi sebagai salah satu faktor yang cukup besar mempengaruhi kinerja karyawan pada Autotama Mobil Motor di Karangasem belum begitu banyak diperhatikan oleh perusahaan. Berdasarkan pengamatan yang dilakukan bahwa karyawan Autotama Mobil Motor di Karangasem mepunyai motivasi berprestasi yang masih rendah. Indikasi tersebut dapat dilihat dari cara kerjanya yang masih secara berkelompok atau grup yang mana hal tersebut mencerminkan kurangnya memiliki rasa tanggung jawab pribadi serta kurang percaya diri dalam mengerjakan suatu pekerjaan.

Melihat indikasi tersebut, kinerja karyawan pada Autotama Mobil Motor Karangasem dipengaruhi oleh beberapa variabel. Salah satu diantaranya adalah motivasi berprestasi, namun seberapa besar hubungan atau determinasi dari motivasi berprestasi terhadap kinerja karyawan Autotama Mobil Motor belum diketahui secara pasti. Maka dari itu, penelitian ini akan meneliti tentang determinasi motivasi berprestasi terhadap kinerja pegawai Autotama Mobil Motor di Karangasem.

Tujuan penelitian ini adalah untuk mengetahui apakah terdapat determinasi motivasi berprestasi yang signifikan terhadap kinerja karyawan Autotama Mobil Motor di Karangasem.

\section{TINJAUAN PUSTAKA}

Sumber daya manusia merupakan salah satu unsur yang sangat menentukan keberhasilan suatu organisasi mencapai tujuan, orang merupakan unsur yang sangat penting dalam organisasi. Untuk mencapai tujuan organisasi maka salah satu hal yang perlu dilakukan manajer adalah memberikan daya pendorong yang mengakibatkan, menyalurkan, dan memelihara perilaku para pegawai agar bersedia bekerja sesuai dengan yang diinginkan organisasi. Daya pendorong tersebut disebut sebagai motivasi. Motivasi juga merupakan subyek yang membingungkan, karena motivasi tidak dapat diamati atau diukur secara langsung, tetapi harus disimpulkan dari perilaku orang yang tampak dan bisa diamati langsung.

Dalam melakukan suatu pekerjaan setiap karyawan membutuhkan motivasi yang ada pada dirinya agar timbul suatu semangat atau kegairahan dalam bekerja Ada dua rangsangan motivasi yaitu dari dalam diri karyawan itu sendiri dan dari faktor luar karyawan. Setiap karyawan memiliki perbedaan motivasi pada dirinya dalam bekerja ada yang menginginkan suatu penghargaan yang diberikan oleh perusahaan dimana ia bekerja dan rasa puas dalam mengerjakan suatu pekerjaan yang hanya bisa dirasakan oleh dirinya sendiri.

Motivasi mewakili proses-proses
psikologikal, yang menyebabkan 
timbulnya, diarahkannya, dan terjadinya persistensi kegiatan-kegiatan suka rela yang diarahkan ke arah tujuan tertentu.

Sehubungan dengan motivasi kerja, maka pemberdayaan menjadi isu yang sangat berkaitan. Karena pemberdayaan akan mampu memberikan stimulus bagi karyawan agar termotivasi untuk bekerja. Karyawan yang diberdayakan dengan baik akan memberikan kinerja terbaiknya, selama hal tersebut diiringi dengan kompensasi yang memadai. Pemberdayaan yang tepat akan memberikan kontribusi bagi optimalisasi kinerja organisasi maupun perusahaan.

Motivasi berasal dari kata latin movere yang berarti dorongan, daya penggerak atau kekuatan yang menyebabkan suatu tindakan atau perbuatan. Kata movere dalam bahasa Inggris, sering disepadankan dengan motivation yang berarti pemberian motif, penimbulan motif, atau hal yang menimbulkan dorongan atau keadaan yang menimbulkan dorongan. Secara harfiah, motivasi berarti pemberian motif. Seseorang melakukan suatu tindakan pada umumnya mempunyai suatu motif. Seseorang melakukan sesuatu dengan sengaja, tentu ada suatu maksud atau tujuan yang mendorongnya melakukan suatu tindakan. Motif dasar dari seseorang tersebut adalah adanya kebutuhan orang tersebut akan kebanggan dan kehormatan serta mungkin limpahan materi.

Robbins (2006) menyatakan motivasi kerja sebagai kesediaan untuk melaksanakan upaya tinggi untuk mencapai tujuan-tujuan keorganisasian yang dikondisikan oleh kemampuan upaya untuk memenuhi kebutuhan individual tertentu. Motivasi yang ada pada diri seseorang merupakan pendorong yang akan mewujudkan suatu perilaku guna mencapai tujuan kepuasan dirinya. Orang mau bekerja untuk memenuhi kebutuhan, baik kebutuhan yang disadari (conscious needs) maupun kebutuhan/keinginan yang tidak disadari (unconcious needs), demikian juga orang mau bekerja untuk mendapatkan kebutuhan fisik dan mental.

Motivasi memegang peranan penting dalam pencapaian tujuan. Motivasi berprestasi pada dasarnya adalah program untuk mencapai suatu pekerjaan atau untuk berprestasi yang dimiliki oleh seorang individu (Sukari, 1999). Istilah kinerja sering digunakan dalam penelitian yang bersifat ilmiah berkenaan dengan proses kerja yang telah dilakukan oleh individu atau kelompok.

Kinerja berasal dari istilah "performance" atau unjuk kerja. Menurut Kane (1996) kinerja bukan merupakan karakteristik seseorang, seperti bakat atau kemampuan, tetapi merupakan perwujudan dari bakat atau kemampuan itu sendiri. Hal ini dimaksudkan bahwa kinerja merupakan perwujudan dari kemampuan dalam bentuk karya nyata. Kinerja dalam jabatan berarti hasil yang dicapai yang berkaitan dengan fungsi jabatan dalam periode waktu tertentu. (Kane, 1996).

Prawirosentono

mendifinisikan kinerja sebagai hasil 
kerja yang dapat dicapai oleh seseorang atau sekelompok orang dalam suatu organisasi dalam rangka upaya mencapai tujuan secara legal.

Ilyas (1999) mengatakan bahwa kinerja adalah penampilan hasil karya personil baik kuantitas maupun kualitas dalam satu organisasi dan merupakan penampilan individu maupun kelompok kerja personil. Deskripsi kinerja meliputi: 1) tujuan yang artinya bahwa penentuan tujuan merupakan strategi yang digunakan untuk meningkatkan kinerja, 2) ukuran yang artinya dibutuhkan ukuran apakah seorang personil telah mencapai kinerja yang diharapkan. Standar kinerja secara kuantitatif dan kualitatif untuk setiap tugas dan jabatan memegang peranan penting, dan 3) penilaian yaitu penilaian kinerja secara regular yang dikaitkan dengan proses pencapaian tujuan kinerja setiap personel. Pengertian kinerja dengan deskripsi tujuan, ukuran operasional, dan penilaian secara regular mempunyai peran yang amat penting di dalam meningkatkan motivasi personel.

Untuk mengetahui kinerja seseorang ada dua konsep utama yang mesti diperhatikan yaitu efisiensi dan efektifitas (Handoko, 1998). Efisiensi berarti dapat memaksimalkan pengeluaran dengan masukan yang terbatas. Sedangkan efektifitas adalah kemampuan untuk memilih tujuan yang tepat atau peralatan yang tepat untuk mencapai tujuan yang telah ditetapkan. Ruky (2001) mengatakan bahwa apa yang terjadi dalam sebuah pekerjaan adalah sebuah proses yang mengolah input menjadi output (hasil kerja). Dengan demikian penilaian kinerja karyawan dalam penelitian ini menggunakan pendekatan input-prosesoutput.

Porter dan Miles dalam Winardi (2002) menyatakan bahwa ada tiga variabel yang mempengaruhi kinerja seseorang yaitu: 1) karakteristik individu (minat, sikap, dan kebutuhan), karakteristik pekerjaan (tingkat otonomi, jumlah umpan balik, dan prestasi langsung), karakteristik situasi (lingkungan kerja dan iklim organisasi); 2) kemampuan, dan 3) prestasi peran. Ketiga variabel itu saling berhubungan dan bila salah satu dari variabel tersebut terhambat maka kinerja akan menurun.

Hipotesis merupakan dugaan sementara berdasarkan teori yang telah dikaji. Berdasarkan teori-teori dan kerangka berpikir yang dipaparkan di atas, maka hipotesis yang diajukan dalam penelitian ini adalah "terdapat determinasi yang signifikan antara motivasi berprestasi terhadap kinerja karyawan pada Autotama Mobil Motor di Karangasem".

\section{METODE PENELITIAN}

Variabel bebas adalah variabel yang mempengaruhi terhadap segala sesuatu gejala. Variabel bebas dalam penelitian ini adalah motivasi berprestasi (X). Variabel terikat adalah variabel yang dipengaruhi oleh suatu gejala. Dalam penelitian ini yang 
menjadi variabel terikat adalah kinerja karyawan $(\mathrm{Y})$.

Motivasi berprestasi adalah kiat-kiat dorongan yang ada dalam diri individu untuk berusaha bekerja semaksimal mungkin sehingga hasil pekerjaan dapat tercapai secara optimal. Kinerja karyawan merupakan perwujudan dari kemampuan karyawan dalam bentuk karya nyata maupun perbuatan dalam menyelesaikan tugasnya.

Menurut Sugiyono (2008) populasi adalah wilayah generalisasi yang terdiri atas: objek atau subjek yang mempunyai kualitas dan karateristik tertentu yang ditetapkan oleh peneliti untuk dipelajari dan kemudian ditarik kesimpulannya. Populasi dalam penelitian ini adalah seluruh karyawan Autotama Mobil Motor di Karangasem yang berjumlah 49 orang.

Sampel penelitian adalah sebagain dari populasi yang diambil dianggap mewakili seluruh populasi dan diambil menggunakan teknik tertentu. Menurut (Agung, 2011) bila populasi besar dan peneliti tidak mungkin mempelajari semua yang ada populasi, misalnya keterbatasan dana, tenaga, dan waktu maka peneliti dapat menggunakan sampel yang diambil dari populasi itu. Apa yang dipelajari dari sampel itu, kesimpulannya akan diberlakukan untuk populasi. Untuk itu sampel yang diambil dari populasi harus betul-betul resprentatif. Dalam penelitian ini populasi penelitian kurang 100 orang. Sehingga seluruh populasi yang berjumlah
49 orang langsung dijadikan sampel penelitian.

Metode pengumpulan data diterapkan guna memperoleh data secara empiris mengenai variabel yang diteliti. Dalam penelitian ini, untuk mengumpulkan data yang diperlukan, penulis menggunakan beberapa metode sebagai berikut: (1) Observasi adalah teknik pengumpulan data yang dilakukan dengan pengamatan langsung terhadap karyawan dalam melaksanakan pekerjaannya. Melalui teknik ini dapat diamati kinerja karyawan serta hal- hal yang berhubungan dengan kondisi lingkungan kerja serta peralatan yang digunakan; (2) Wawancara adalah teknik pengumpulan data yang dilakukan dengan melakukan tanya jawab kepada para responden untuk memperoleh informasi yang diperlukan dalam proses penelitian ini. Data yang diperoleh dari hasil wawancara yaitu penempatan karyawan sesuai dengan pendidikannya, pengalaman dan kemampuan kerja, kesesuaian kompensasi yang diberikan oleh instansi, peluang promosi, sikap rekan dan kondisi lingkungan; (3) Studi kepustakaan/studi dokumentasi adalah teknik pengumpulan data dengan membaca buku- buku dan literatur atau tulisan ilmiah yang berhubungan dengan masalah yang diteliti; (4) Kuesioner adalah metode pengumpulan data dengan menggunakan daftar pertanyaan yang disebarkan kepada responden untuk dimintai keterangan mengenai sesuatu yang dialami yang berhubungan dengan masalah yang dibahas 
dalam penelitian ini. Data yang didapat dari kuesioner adalah respons karyawan mengenai motivasi berprestasi dan kinerja karyawan.

Data yang sudah dikumpulkan ditabulasi rerata, median, modus, rentangan, besaran dan simpangan baku menyangkut data motivasi berprestasi dan kinerja karyawan. Analisis statistik yang digunakan untuk menguji hipotesis adalah dengan regresi linier sederhana. Adapun tahapan analisis yang dilakukan dalam penelitian ini adalah sebagai berikut:

Data motivasi berprestasi dan kinerja pegawai berdasarkan tendensi data, meliputi mean, median, modus, standar deviasi, varians, rentangan skor maksimum, dan skor minimum. Sebaran motivasi berprestasi dan kinerja pegawai disajikan dalam bentuk tabel dan gambar diagram untuk masing-masing model pembelajaran.

Kualifikasi pendeskripsian data motivasi berprestasi dan kinerja karyawan, juga menggunakan analisis univariant. Analisis ini didasarkan pada skor rata-rata ideal (Mi) dan simpangan baku ideal (SDi). Kriteria kualifikasi motivasi berprestasi dan kinerja karyawan digolongkan menjadi 5 (lima) dan disusun seperti pada Tabel 1. 
Tabel 1 Pedoman Konversi Motivasi Berprestasi dan Kinerja Karyawan

\begin{tabular}{|l|c|}
\hline \multicolumn{1}{|c|}{ Kriteria } & Kualifikasi \\
\hline $\mathrm{X}>(\mathrm{Mi}+1,5 \mathrm{SDi})$ & Sangat Tinggi \\
\hline$(\mathrm{Mi}+0,5 \mathrm{SDi})<\mathrm{X} \leq(\mathrm{Mi}+1,5 \mathrm{SDi})$ & Tinggi \\
\hline$(\mathrm{Mi}-0,5 \mathrm{SDi})<\mathrm{X} \leq(\mathrm{Mi}+0,5 \mathrm{SDi})$ & Sedang \\
\hline$(\mathrm{Mi}-1,5 \mathrm{SDi})<\mathrm{X} \leq(\mathrm{Mi}-0,5 \mathrm{SDi})$ & Rendah \\
\hline $\mathrm{X} \leq(\mathrm{Mi}-1,5 \mathrm{SDi})$ & Sangat Rendah \\
\hline
\end{tabular}

Sumber: Data sekunder

Keterangan:

Mi $\quad$ rata-rata ideal $=1 / 2($ skor maksimum ideal + skor minimum ideal $)$

SDi $\quad$ : simpangan baku ideal $=1 / 6$ (skor maksimum ideal - skor minimum ideal)

Pengujian asumsi dilakukan untuk mengetahui bahwa data yang tersedia dapat dianalisis dengan parametrik atau tidak. Berkaitan dengan statistik yang digunakan untuk analisis data dalam penelitian ini, uji asumsi yang dilakukan meliputi uji normalitas sebaran data dan uji linieritas dan keberartian koefisien arah regresi.

Untuk menguji hipotesis dalam penelitian ini digunakan teknik analisis korelasi product moment (Sudjana, 2006). Untuk mengetahui signifikan nilai $r$ tersebut, dikonsultasikan dengan nilai $\mathrm{r}_{\text {tabel }}$. Kaidah keputusannya dengan menggunakan $\alpha=0,05$, jika $r_{\text {hitung }}>r_{\text {tabel }}(p$ $<$ 0,05), maka H0 ditolak, berarti signifikan. Sebaliknya jika $\mathrm{r}_{\text {hitung }}<\mathrm{r}_{\text {tabel }}(\mathrm{p}<$ 0,05), maka H0 diterima, berarti tidak signifikan. Selanjutnya untuk memprediksi variabel bebas terhadap variabel terikat digunakan analisis regresi sederhana dengan rumus:

$$
\hat{\mathrm{Y}}=\mathrm{a}+\mathrm{bX} \quad \text { (Sudjana, 2006) }
$$

Untuk menguji signifikansi garis regresi di atas digunakan rumus: (Hadi, 2003).
$\mathrm{F}_{\text {res }}=$ dengan derajat kebebasan $(\mathrm{dk})=1:(\mathrm{n}-2)$

Dimana:

- $\mathrm{n} \quad=$ Banyaknya sampel

- $\mathrm{F}_{\text {res }} \quad$ Harga bilangan $\mathrm{F}$ untuk garis regresi

- $\mathrm{JK}_{\text {reg }}=$ Rerata jumlah kuadrat garis regresi

- $\mathrm{RJK}_{\text {reg }}=$ Rerata jumlah kuadrat garis residu

Kaidah keputusannya adalah dengan menggunakan $\alpha=0,05$ dan $\mathrm{dk}=1:(\mathrm{n}-2)$, jika $F r_{\text {hitung }}>\mathrm{F}$ tabel $(\mathrm{P}<0,05)$, maka garis regresi tersebut signifikan, dan sebaliknya jika $\mathrm{F}_{\text {hitung }}<\mathrm{F}_{\text {tabel }}(\mathrm{P}>0,05)$, maka garis regresi tidak signifikan. Untuk keperluan analisis digunakan program SPSS-21.00 for windows.

Penelitian ini dilakukan di Autotama Mobil Motor di Karangasem yang beralamat di Jalan Raya Jasri, Subagan, Kecamatan Karangasem, Kabupaten Karangasem dari bulan Februari - Juli 2015. 
HASIL DAN PEMBAHASAN

\section{Deskripsi Data Hasil Penelitian}

Objek penelitian ini adalah motivasi berprestasi dan kinerja karyawan Autotama Mobil Motor di Karangasem. Gambaran mengenai karakteristik distribusi skor dari masing-masing objek penelitian, berikut disajikan skor tertinggi, skor terendah, harga rerata, simpangan baku, varians, median, modus, distribusi frekuensi, histogram, dan klasifikasi masing-masing objek yang diteliti.

Tabel 2 Rekapitulasi Deskriptif Statistik Masing-Masing Variabel

\begin{tabular}{|l|c|c|}
\hline & Motivasi Berprestasi & Kinerja Pegawai \\
\hline Rerata & 116.63 & 36.96 \\
Median & 117 & 38 \\
Modus & 116 & 40 \\
Std. Deviasi & 5.07 & 4.64 \\
Besaran & 25.74 & 21.54 \\
Rentangan & 20 & 16 \\
Skor Terendah & 105 & 28 \\
Skor Tertinggi & 125 & 44 \\
\multicolumn{1}{|c|}{ Total } & $\mathbf{5 7 1 5}$ & $\mathbf{1 8 1 1}$ \\
\hline
\end{tabular}

Sumber: Data primer

Skor Motivasi Berprestasi diperoleh dari hasil pencatatan dokumen yang menunjukan bahwa skor terendah $=105$, skor tertinggi $=125$, rentangan $=20$, ratarata $=116,63$, standar deviasi $=5,07$, modus $=116$, dan median $=117$. Distribusi frekuensi skor motivasi berprestasi dapat diringkaskan seperti Tabel 3. 
Tabel 3 Distribusi Frekuensi Skor Motivasi Berprestasi

\begin{tabular}{|c|c|c|c|c|}
\hline \multirow{2}{*}{ No } & \multirow{2}{*}{ Kelas Interval } & \multirow{2}{*}{ Nilai Tengah } & \multicolumn{2}{|c|}{ Frekuensi } \\
\cline { 4 - 5 } & & & Absolut & Relatif \\
\hline 1 & $105-107$ & 106 & 2 & 4,08 \\
\hline 2 & $108-110$ & 109 & 6 & 12,24 \\
\hline 3 & $111-113$ & 112 & 4 & 8,16 \\
\hline 4 & $114-116$ & 115 & 12 & 24,49 \\
\hline 5 & $117-119$ & 118 & 9 & 18,37 \\
\hline 6 & $120-122$ & 121 & 10 & 20,41 \\
\hline 7 & $123-125$ & 124 & 6 & 12,24 \\
\hline & Jumlah & & $\mathbf{4 9}$ & $\mathbf{1 0 0}$ \\
\hline
\end{tabular}

Agar tampak lebih jelas, maka data dalam Tabel 3 disajikan dalam bentuk Gambar-1

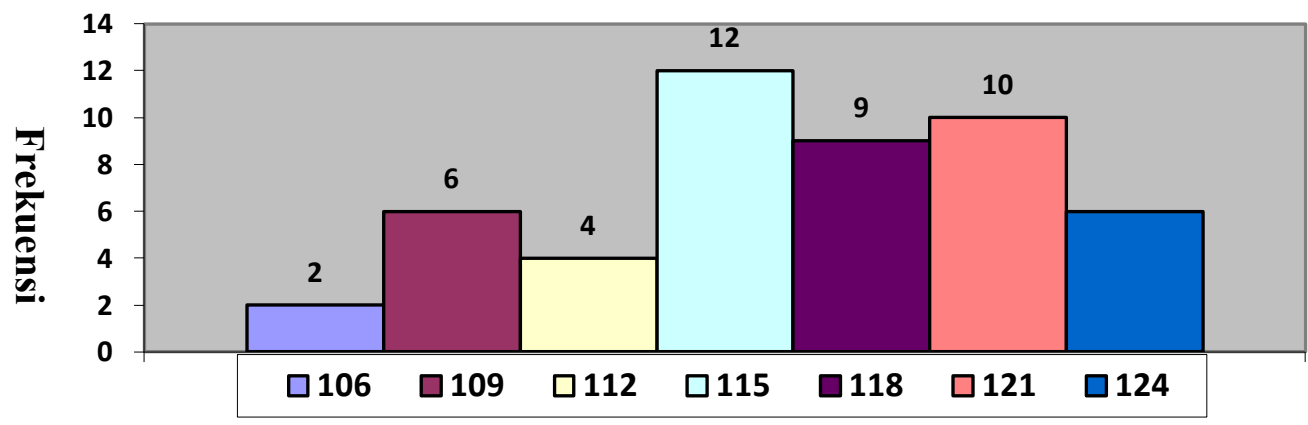

\section{Interval}

Gambar 1 Histogram Motivasi Berprestasi

Sumber: Data sekunder.

Untuk mengetahui kecendrungan klasifikasi data motivasi berprestasi dengan menghitung rata-rata ideal (Mi) dan standar deviasi ideal (SDi) di mana $\mathrm{Mi}=1 / 2$ $\mathrm{x}$ (skor maksimal ideal + skor minimal ideal $)=1 / 2 \times(145+29)=87 . \mathrm{SDi}=1 / 6 \mathrm{x}$ (skor maksimal ideal - skor minimal ideal)

1. $(\mathrm{Mi}+1,5 \mathrm{SDi})<\mathrm{A}$

2. $(\mathrm{Mi}+0,5 \mathrm{SDi}) \leq \mathrm{B}<(\mathrm{Mi}+1,5 \mathrm{SDi})$

3. $(\mathrm{Mi}-0,5 \mathrm{SDi}) \leq \mathrm{C}<(\mathrm{Mi}+0,5 \mathrm{SDi})$

4. $(\mathrm{Mi}-1,5 \mathrm{SDi}) \leq \mathrm{D}<(\mathrm{Mi}-0,5 \mathrm{SDi})$

5. $\mathrm{E}<(\mathrm{Mi}-1,5 \mathrm{SDi})$

Berdasarkan perhitungan dapat dibuat tabel konversi kategorinya seperti tertera pada Tabel 4.
$=1 / 6 \times(145-29)=19,33$. Berdasarkan hasil perhitungan tersebut, selanjutnya dapat disusun tabel konversi kategori data motivasi berprestasi dengan formula konversi yang dikelompokkan menjadi 5 (lima) kategori berdasarkan pedoman konversi pada norma relatif skala berikut:

= sangat baik

$=$ baik

$=$ sedang

$=$ kurang baik

= sangat kurang baik 
Tabel 4 Kategori Data Motivasi Berprestasi

\begin{tabular}{|l|l|c|c|c|}
\hline No & \multicolumn{1}{|c|}{ Kriteria } & Klasifikasi & Jumlah & \% \\
\hline & $116 \leq \mathrm{A}$ & Sangat baik & 31 & 63,27 \\
\hline & $96,67 \leq \mathrm{B}<116$ & Baik & 18 & 36,73 \\
\hline & $77,34 \leq \mathrm{C}<96,67$ & Sedang & 0 & 0 \\
\hline & $58,01 \leq \mathrm{D}<77,34$ & Kurang baik & 0 & 0 \\
\hline & $\mathrm{E}<58,01$ & Sangat kurang baik & 0 & 0 \\
\hline \multicolumn{2}{|c|}{ Jumlah } & $\mathbf{4 9}$ & $\mathbf{1 0 0}$ \\
\hline
\end{tabular}

Berdasarkan tabel kategori yang telah

dibuat diketahui bahwa motivasi

berprestasi termasuk kategori "sangat baik" sebanyak 31 orang $(63,27 \%)$, dan kategori "baik" sebanyak 18 orang $(36,73 \%)$.

Skor Kinerja Pegawai yang diperoleh dari hasil pengukuran terhadap responden menunjukan bahwa skor terendah $=28$, skor tertinggi $=44$, rentangan $=16$, ratarata $=36,96$, standar deviasi $=4,64$, modus $=40$, dan median $=38$. Distribusi frekuensi skor kinerja karyawan dapat diringkaskan seperti Tabel 5.

.Tabel 5 Distribusi Frekuensi Skor Kinerja Karyawan

\begin{tabular}{|c|c|c|c|c|}
\hline \multirow{2}{*}{ No } & \multirow{2}{*}{ Kelas Interval } & \multirow{2}{*}{ Nilai Tengah } & \multicolumn{2}{|c|}{ Frekuensi } \\
\cline { 4 - 5 } & & & Absolut & Relatif \\
\hline 1 & $28-30$ & 29 & 6 & 12,24 \\
\hline 2 & $31-33$ & 32 & 7 & 14,29 \\
\hline 3 & $34-36$ & 35 & 7 & 14,29 \\
\hline 4 & $37-39$ & 38 & 12 & 24,49 \\
\hline 5 & $40-42$ & 41 & 11 & 22,45 \\
\hline 6 & $43-45$ & 44 & 6 & 12,24 \\
\hline & Jumlah & & $\mathbf{4 9}$ & $\mathbf{1 0 0}$ \\
\hline
\end{tabular}

Sumber: Data primer

Agar tampak lebih jelas, maka data dalam Tabel 5 disajikan dalam bentuk Gambar-2.

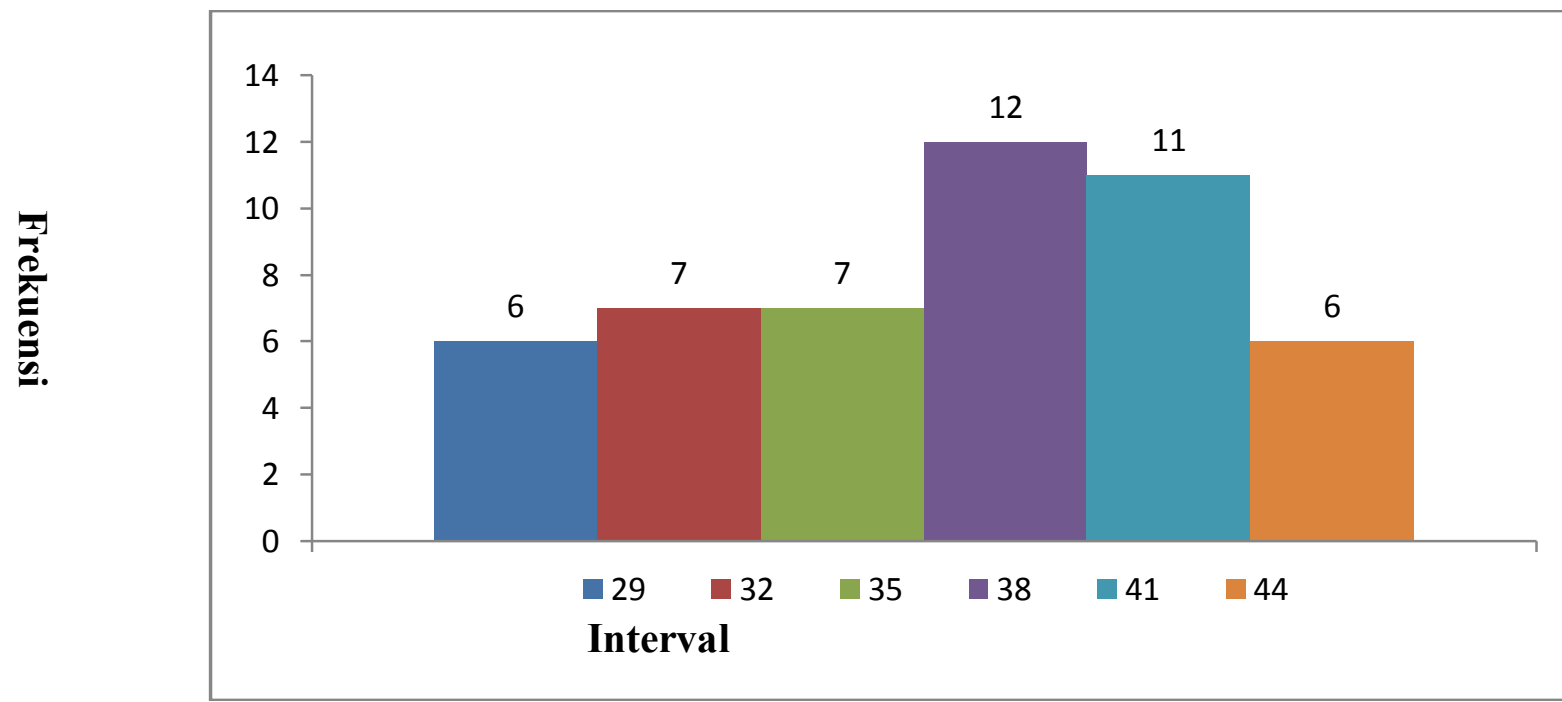

Gambar 2 Histogram Kinerja Karyawan 
Untuk mengetahui kecenderungan klasifikasi data kinerja karyawan dengan menghitung mean ideal (Mi) dan standar deviasi ideal (SDi) dimana $\mathrm{Mi}=1 / 2 \times$ (skor maksimal ideal + skor minimal ideal $)=1 / 2$ $\mathrm{x}(50+10)=30 . \mathrm{SDi}=1 / 6 \mathrm{x}$ (skor maksimal ideal - skor minimal ideal $)=1 / 6$

1. $(\mathrm{Mi}+1,5 \mathrm{SDi}) \leq \mathrm{A}$

2. $(\mathrm{Mi}+0,5 \mathrm{SDi}) \leq \mathrm{B}<(\mathrm{Mi}+1,5 \mathrm{SDi})$

3. $(\mathrm{Mi}-0,5 \mathrm{SDi}) \leq \mathrm{C}<(\mathrm{Mi}+0,5 \mathrm{SDi})$

4. $(\mathrm{Mi}-1,5 \mathrm{SDi}) \leq \mathrm{D}<(\mathrm{Mi}-0,5 \mathrm{SDi})$

5. $\mathrm{E}<(\mathrm{Mi}-1,5 \mathrm{SDi})$

Berdasarkan perhitungan dapat dibuat tabel konversi kategorinya seperti tertera pada Tabel 6. $\mathrm{x}(50-10)=6,67$. Berdasarkan hasil perhitungan tersebut, selanjutnya dapat disusun tabel konversi kategori data kinerja karyawan dengan formula konversi yang dikelompokkan menjadi lima kategori berdasarkan pedoman konversi pada norma relatif skala lima berikut:

$$
\begin{aligned}
& =\text { sangat baik } \\
& =\text { baik } \\
& =\text { sedang } \\
& =\text { kurang baik } \\
& =\text { sangat kurang baik }
\end{aligned}
$$


Tabel 6 Kategori Data Kinerja Karyawan

\begin{tabular}{|c|l|c|c|c|}
\hline No & \multicolumn{1}{|c|}{ Kriteria } & Klasifikasi & Jumlah & \% \\
\hline 1 & $40 \leq \mathrm{A}$ & Sangat baik & 17 & 34.69 \\
\hline 2 & $33,33 \leq \mathrm{B}<40$ & Baik & 32 & 65.31 \\
\hline 3 & $26,66 \leq \mathrm{C}<33,33$ & Sedang & 0 & 0 \\
\hline 4 & $19,99 \leq \mathrm{D}<26,66$ & Kurang baik & 0 & 0 \\
\hline 5 & $\mathrm{E}<19,99$ & Sangat kurang baik & 0 & 0 \\
\hline
\end{tabular}

Sumber: Data primer

Berdasarkan tabel kategori yang telah dibuat diketahui bahwa kinerja karyawan pada termasuk dalam kategori "sangat baik" dengan 17 orang $(34,69 \%)$ dan dalam kategori "baik" sebanyak 32 orang $(65,31 \%)$.

\section{Uji Prasyarat Analisis}

Uji prasyarat analisis dilakukan sebagai suatu prasyarat analisis data secara statistik. Uji persyaratan analisis dilakukan meliputi: (1) uji normalitas sebaran data dan (2) linieritas garis regresi dan keberartian koefisien regresi.
Pengujian normalitas dilakukan untuk meyakinkan bahwa sampel berasal dari populasi yang berdistribusi normal, sehingga uji hipotesis dapat dilakukan. Uji normalitas data dilakukan pada dua kelompok data yakni data motivasi berprestasi dan data kinerja karyawan. UJi normalitas kedua kelompok data menggunakan SPSS-21.00 for windows uji statistik Kolmogorov-smirnov pada signifikansi 0,05 dengan kriteria sebagai berikut: 
a .Distribusi tidak normal

Sig atau signifikasi $<0,05$
: Jika nilai

Tabel 7. Rekapitulasi Hasil Pengujian Normalitas Sebaran Data dengan Uji Kolmogorov-Smirnov

Sig atau signifikasi $>0,05$

\begin{tabular}{|l|c|c|c|c|}
\hline \multirow{2}{*}{ Variabel } & \multicolumn{2}{|c|}{ Kolmogorov-Smirnov } & \multirow{2}{*}{ Keterangan } \\
\cline { 2 - 4 } & Statistik & f & Sig. & \\
\hline Motivasi Berprestasi & 0,096 & 9 & 0,200 & Distribusi normal \\
\hline Kinerja Karyawan & 0,119 & 9 & 0,080 & Distribusi normal \\
\hline
\end{tabular}

Sumber: Data primer

Berdasarkan Tabel 7 di atas, terlihat bahwa untuk semua variabel angka statistik Kolmogorov-Smirnov yang diperoleh dengan $\mathrm{p}>0,05$, maka $\mathrm{H} 0$ ditolak. Ini berarti skor motivasi berprestasi dan kinerja karyawan berdistribusi normal.

Uji linieritas digunakan untuk mengetahui bentuk korelasi antara variabel terikat dengan masing-masing variabel bebas. Pedoman untuk melihat kelinieran adalah dengan mengkaji lajur Dev. From Linierity dari model Means. Sedangkan untuk melihat keberartian arah regresinya b. Distribusi normal

: Jika nilai 
H0, tidak terdapat determinasi yang signifikan antara motivasi berprestasi terhadap kinerja karyawan Autotama Mobil Motor.

Ha, terdapat determinasi yang signifikan antara motivasi berprestasi terhadap kinerja karyawan Autotama Mobil Motor.

Hipotesis yang menyatakan bahwa terdapat determinasi yang signifikan antara motivasi berprestasi dengan kinerja karyawan. Untuk menguji hipotesis ini digunakan teknik korelasi dan regresi linier sederhana. Hasil perhitungan regresi sederhana $\mathrm{Y}$ atas $\mathrm{X}$, ditemukan persamaan regresi $\hat{y}=-36,800+0,632 X$. Pengujian signifikan dan linieritas hubungan antara motivasi berprestasi (X) dengan kinerja karyawan (Y), seperti tampak pada Tabel 9.

Tabel 9. Uji Signifikansi dan Kelinieran Regresi Kinerja Karyawan terhadap Motivasi Berprestasi

\begin{tabular}{|c|c|c|c|c|c|c|}
\hline \multirow{2}{*}{$\begin{array}{l}\text { Sumber } \\
\text { Variasi }\end{array}$} & \multirow[b]{2}{*}{$\mathbf{k}$} & \multirow{2}{*}{ JK } & \multirow{2}{*}{ RJk } & \multirow{2}{*}{ F hitung } & F tabel & \multirow{2}{*}{ Keterangan } \\
\hline & & & & & $\alpha=0,05$ & \\
\hline Regresi (reg) & 1 & 494,076 & 494,076 & 43,015 & 4,08 & Signifikan \\
\hline Residu (res) & 7 & 539,842 & 11,486 & & & \\
\hline Total & 8 & 1033,918 & & & & \\
\hline \multicolumn{7}{|c|}{ r hitung $=0,691$} \\
\hline Dete & inas & $=0,478$ & & & & \\
\hline
\end{tabular}

Sumber: Data primer

Keterangan:

$\mathrm{dk}=$ derajat kebebasan

$\mathrm{Jk}=$ jumlah kuadrat

$\mathrm{RJk}=$ rerata jumlah kuadrat

Berdasarkan tabel $4.8 \mathrm{di}$ atas dapat disimpulkan bahwa $\hat{y}=-36,800+0,632 X$ dengan Freg $=43,015$ dan determinasi sebesar 0,478 atau $47,8 \%$ adalah signifikan dan linier karena Freg $>$ Ftabel. Ini menunjukkan bahwa baik buruknya kinerja karyawan disebabkan karena motivasi berprestasi yang dapat diprediksikan melalui persamaan garis regresi. Dengan demikian, dapat dikatakan bahwa kenaikan skor variabel motivasi berprestasi diikuti pula oleh kenaikan rata-rata skor kinerja karyawan.
Korelasi antara motivasi berprestasi (X) dengan kinerja karyawan (Y), dihitung dengan korelasi product moment. Berdasarkan analisis dengan komputer diperoleh besar $r_{\text {hitung }}=0,691$. Ini berarti $\mathrm{r}_{\text {hitung }}=0,691$ signifikan pada $\alpha=0,05\left(\mathrm{r}_{\text {tabel }}\right.$ $=0,281)$. Dengan demikian hipotesis nol (H0) yang menyatakan "tidak terdapat determinasi yang signifikan antara motivasi berprestasi dengan kinerja karyawan" ditolak. Hal ini berarti hipotesis penelitian (Ha) yang diajukan yaitu "terdapat determinasi yang signifikan antara motivasi 
berprestasi dengan kinerja karyawan" diterima.

\section{Pembahasan Hasil Penelitian}

Hasil analisis menunjukkan bahwa terdapat korelasi yang signifikan antara motivasi berprestasi dengan kinerja karyawan melaui persamaan garis $\mathrm{y}=$ $36,800+0,632 X$ dengan Freg $=43,015$ $(p<0,05)$. Dalam penelitian ini ditemukan korelasi yang signifikan antara motivasi berprestasi dengan kinerja karyawan sebesar 0,691 dengan $p<0,05$. Ini berarti makin baik motivasi berprestasi karyawan, makin baik kinerja karyawan tersebut. Variabel motivasi berprestasi dapat menjelaskan makin tinggi kinerja karyawan sebesar 47,8\%. Temuan ini mengindikasikan bahwa motivasi berprestasi mempunyai peranan penting dalam meningkatkan kinerja karyawan. Secara normatif ditemukan bahwa motivasi berprestasi berada pada kategori sangat baik, artinya pegawai sudah menunjukan motivasi berprestasi yang sangat baik dalam menjalankan pekerjaannya.

Hasil penelitian ini sejalan dengan hasil penelitian yang dilaksanakan oleh Dewa (2011) yang berjudul pengaruh motivasi berprestasi dan gaya kepemimpinan terhadap kinerja pegawai Badan Kepegawaian, Pendidikan dan Pelatihan Kabupaten Aceh Singkil. Dalam penelitiannya dinyatakan bahwa secara parsial baik motivasi berprestasi maupun kepemimpinan berpengaruh signifikan terhadap kinerja. Demikian juga secara bersama-sama motivasi berprestasi dan kepemimpinan berpengaruh signifikan terhadap kinerja pegawai Badan Kepegawaian, Pendidikan, dan Pelatihan Kabupaten Aceh Singkil dengan sumbangan determinasi sebesar 51,1 \% dengan persamaan regresi $\mathrm{Y}=7,869+$ $0,295 \mathrm{Xl}+0,767 \mathrm{Xl}+$ e Kedua variabel secara bersama-sama terdapat pengaruh yang signifikan antara variabel motivasi berprestasi dan variabel gaya kepemimpinan terhadap variabel kinerja pegawai sebesar $64,7 \%$, sedangkan sisanya sebesar 35,3\% yang merupakan faktor lain yang tidak dibahas daIam penelitian tersebut.

Motivasi berprestasi adalah kiat-kiat atau dorongan yang ada dalam diri individu untuk berusaha bekerja semaksimal mungkin sehingga capai kerja dapat tercapai secara optimal. Orang yang memiliki motivasi berprestasi cenderung memiliki kemauan keras, dan menyukai pekerjaan yang menantang dan terukur.

Kemauan keras yang muncul dalam diri seseorang menunjukkan adanya energi yang kuat untuk berusaha mencapai hasil yang diharapkan. Munculnya kemauan pada diri seseorang menimbulkan ketidakseimbangan yang menuntut pemenuhun. Dorongan untuk memenuhi kemauan inilah yang disebut motivasi. Bila kemauan itu terkait dengan kinerja, di mana dalam diri seseorang muncul kebutuhan akan keberhasilan dalam kinerja, maka akan timbul energi dalam dirinya untuk bergerak melakukan pekerjaan-pekerjaan yang mengarah pada pencapaian 
keberhasilan kinerja itu sendiri. Bila kemauannya besar, maka akan menimbulkan dorongan yang kuat. Dalam kondisi seperti inilah maka seseorang dapat dikatakan memiliki motivasi berprestasi yang tinggi. Berdasarkan pemaparan di atas maka dapat disimpulkan bahwa motivasi berprestasi memiliki pengaruh terhadap kinerja karyawan.

\section{SIMPULAN DAN SARAN}

Berdasarkan uraian dari bab-bab sebelumnya, maka dalam penelitian ini penulis dapat menarik kesimpulan sebagai berikut:

Berdasarkan kategori data motivasi berprestasi, diketahui bahwa motivasi berprestasi termasuk kategori sangat baik sebanyak 31 orang $(63,27 \%)$, dan kategori baik sebanyak 18 orang $(36,73 \%)$.

Berdasarkan kategori data kinerja karyawan, diketahui bahwa kinerja karyawan masuk dalam kategori sangat baik sebanyak 17 orang $(34,69 \%)$, dan dalam kategori baik sebanyak 32 orang $(65,31 \%)$.

Berdasarkan hasil uji normalitas sebaran data terlihat bahwa untuk semua variabel angka statistik kolmogorovsmirnov yang diperoleh dengan $\mathrm{p}>0,05$. Yang berarti skor motivasi berprestasi dan kinerja karyawan berdistribusi normal.

Berdasarkan hasil analisis uji linieritas dan keberartian koefisien regresi menunjukkan bahwa regresinya adalah linier dan keberartian arah regresinya adalah berarti. Hal itu dikarenakan harga
Sig. Dev From Linierity $>0,05$ dan harga Sig. linierity $<0,05$.

Berdasarkan hasil uji signifikan dan kelinieran regresi kinerja karyawan atas motivasi berprestasi dapat disimpulkan bahwa $\hat{y}=-36,800+0,632 X$ dengan Freg $=$ 43,015 dan determinasi sebesar 0,478 atau $47,8 \%$ adalah signifikan dan linier. Karena Freg $>$ Ftabel. Ini menunjukan bahwa baik buruknya kinerja karyawan disebabkan karena motivasi berprestasi yang dapat diprediksikan melalui persamaan garis regresi.

Korelasi antara Motivasi Berprestasi (X) dengan Kinerja Karyawan (Y), dihitung dengan korelasi product moment. Berdasarkan hasil analisis diperoleh besar $\mathrm{r}_{\text {hitung }}=0,691$. Ini berarti $\mathrm{r}_{\text {hitung }}=0,691$ signifikan pada $\alpha=0,05\left(\mathrm{r}_{\text {tabel }}=0,281\right)$. Dengan demikian hipotesis nol (H0) yang menyatakan "tidak terdapat determinasi yang signifikan antara motivasi berprestasi dengan kinerja karyawan" ditolak. Hal ini berarti hipotesis penelitian (Ha) yang diajukan yaitu "terdapat determinasi yang signifikan antara motivasi berprestasi dengan kinerja karyawan" diterima.

Adapun saran yang dapat diajukan sesuai dengan hasil penelitian adalah sebagai berikut:

Mengingat bahwa motivasi berprestasi memberikan determinasi yang signifikan terhadap kinerja karyawan, maka dari itu diarahkan kepada seluruh karyawan untuk meningkatkan motivasi berprestasi dalam dirinya sehingga pekerjaan yang dilakukan mendapatkan hasil yang maksimal. 
Dari hasil analisis korelasi diketahui terdapat determinasi yang signifikan antara motivasi berprestasi dengan kinerja karyawan. Hal tersebut perlu dipertahankan agar karyawan selalu nyaman dan puas dalam melaksanakan tugas sehari-hari sehingga tujuan perusahaan akan tercapai.

Mengingat masih banyak faktor lain yang mempengaruhi kinerja karyawan, maka sudah sewajarnya apabila pinpinan perusahaan memperhatikan faktor-faktor lain tersebut seperti motivasi finansial, kepeminpinan, dan lain sebagainya.

\section{DAFTAR PUSTAKA}

Agung, A. A. Gede. 2011. Metodelogi Penelitian Pendidikan (Suatu Pengantar). Singaraja: Fakultas Ilmu Pendidikan Universitas Pendidikan Ganesha.

Dewa. 2011. Pengaruh Motivasi Berprestasi dan Gaya Kepemimpinan terhadap Kinerja Pegawai Badan Kepegawaian, Pendidikan dan Pelatihan Kabupaten Aceh Singkil. Tesis tidak diterbitkan. Universitas Terbuka.

Hadi, Sutrisno. 2003. Analisis Regresi. Yogyakarta: Andi.

Handoko, H. 1998. Manajemen Personalia dan sumber Daya Manusia. Yogyakarta: BBFE.

Ilyas, B. 1999. Perpajakan Indonesia, Jakarta: Salemba.

Kane, Mc. L. 1996. Microbiologi Applied \& Practice. Mc-Graw. New York: Hill Book Company.

Prawirosentono, S. 1999. Manajemen Sumber Daya Manausia, Kebijakan Kinerja Karyawan. Yogyakarta: BPFE.
Robbins, Stephen P. 2006. Perilaku Organisasi. Jakarta: Indeks.

Ruky, Achmad S. 2001. Sistem Manajemen Kinerja. Jakarta: PT Gramedia.

Soedaryono. 2000. Tata Laksana Kantor. Jakarta: Depdikbud.

Sudjana. 2006. Metode Statistika. Bandung: Tarsito.

Sugiyono. 2008. Metode Penelitian Pendidikan, Pendekatan Kuantitatif, Kualitatif, dan $R$ \& D. Bandung; Alfabeta.

Sukari. 1999. Studi Korelasional Antara Persepsi Widyaniswara Terhadap Jabatannya dan Motivasi berprestasi dengan kinerja Widyaswara. Jurnal Teknologi Pendidikan Nomor 1 .

Winardi, J. 2002. Motivasi dan Pemotivasian dalam Manajemen. Jakarta: PT. Raja Grafindo Persada. 

